\title{
Analisis Proksimat Abon Bonggol Pisang Dengan Fortifikasi Tepung Tempe Dan Lesitin
}

\section{Proximate Analysis of Shredded Banana Corm With Tempeh Flour And Lechitin Fortification}

\author{
Rini Rahayu Sihmawati ${ }^{1}$, Dwi Agustiyah Rosida ${ }^{2}$ \\ ${ }^{1,2}$ Fakultas Vokasi, Program Studi Agroindustri ,Universitas 17 Agustus 1945, \\ Jalan Semolowaru 45 Surabaya 60119 \\ Email: rinirahayus@untag-sby.ac.id ${ }^{1}$
}

\begin{abstract}
Abstrak
Tujuan penelitian ini adalah melakukan uji proksimat (protein, lemak, kadar air dan karbohidrat) abon bonggol pisang dengan fortifikasi tepung tempe dan lesitin. Penelitian ini merupakan penelitian eksperimental dengan menggunakan Rancangan Acak Lengkap pola faktorial. Perlakuan pertama adalah: Tepung Tempe kedele (T) dengan taraf T1 (5\%), T2 (10\%) dan T3 (15\%). Perlakuan kedua adalah lesitin (L) dengan taraf L1 (3\%), L2 (5\%) dan L3 (7\%) sehingga diperoleh 9 kombinasi perlakuan. Data yang terkumpul dianalisis dengan uji varian (analisis ragam) klasifikasi 2 arah. Apabila terdapat perbedaan diantara perlakuan dilanjutkan dengan uji BNT. Hasil uji proksimat terhadap kadar protein abon bonggol pisang menunjukkan bahwa penambahan tepung tempe kedele $(\mathrm{T})$ berpengaruh sangat signifikan terhadap kadar protein $(\mathrm{P}<0.01)$, sedangkan penambahan lesitin $(\mathrm{L})$ tidak significan $(\mathrm{P}>0.05)$ Tepung tempe kedele maupun lesitin keduanya tidak signifikan terhadap kadar lemak dan kadar air $(\mathrm{P}>0.05)$. Tepung tempe kedele $(\mathrm{T})$ berpengaruh sangat signifikan terhadap kadar karbohidrat $(\mathrm{P}<0.01)$, sedangkan penambahan lesitin (L) tidak signifikan $(\mathrm{P}>0.05)$.
\end{abstract}

Kata kunci: bonggol pisang, abon, tepung tempe, lesitin, uji proksimat

\begin{abstract}
The aim of this research was to evaluate a proximate test (protein, fat, water content and carbohydrate) shredded banana corm with tempeh flour and lechitin fortification. This research is an experimental study using a completely randomized design factorial pattern. The first treatment was: Tempe soybean flour $(T)$ with a level of T1 (5\%), T2 (10\%) and T3 (15\%). The second treatment was lecithin (L) with levels of L1 (3\%), L2 (5\%) and L3 $(7 \%)$ so that 9 treatment combinations were obtained. The collected data were analyzed with a 2-way classification variance test (analysis of variance). If there is a difference between treatments followed by LSD test. Proximate test results on the protein content of shredded banana corm showed that the addition of tempeh flour $(T)$ had a very significant effect on protein content $(P<0.01)$, while the addition of lecithin $(L)$ was not significant $(P>0.05)$ both tempeh flour and lechitin did not significant on fat content and water content $(P>0.05)$. Tempeh flour $(T)$ has a very significant effect on carbohydrate content $(P<0.01)$, while the addition of lecithin $(L)$ is not significant $(P>0.05)$.
\end{abstract}

Keywords: banana corn, shredded, tempeh flour, lecithin, proximate test

\section{PENDAHULUAN}

Tanaman pisang merupakan salah satu komoditi hortikultura yang melimpah di Indonesia, yang hanya dimanfaatkan daging buahnya saja, sedangkan bagian-bagian lainnya seperti daun, pelepah dan bonggol hanya untuk pakan ternak atau dibiarkan saja sebagai limbah maupun pupuk kompos (Suyanti dan Supriyadi, 2008).

Bonggol pisang (umbi pisang) merupakan bagian yang paling jarang digunakan apalagi untuk dikonsumsi oleh manusia (Munadjim, 2006). Menurut penelitian Yuanita (2008), bonggol pisang memiliki kandungan air (20\%), mineral $(3,10 \%)$, karbohidrat $(66,2 \%)$ serat $(2,96 \%)$. Kandungan karbohidrat yang tinggi dalam bonggol pisang dapat menjadi bahan subsitusi beras untuk menjadi sumber energi. Bonggol pisang mengandung protein sangat rendah sehingga pembuatan abon yang terbuat dari abon bonggol pisang saja sangat kurang proteinnya dibandingkan abon hewani. Salah satu bahan pangan yang dapat ditambahkan untuk meningkatkan kandungan protein bonggol pisang adalah tepung tempe dan lesitin. 
Masyarakat Indonesia sudah sejak lama mengenal tempe. Tempe merupakan bahan pangan yang dibuat dari kedelai kukus melalui proses yang disebut dengan fermentasi dengan menambahkan ragi tempe yaitu dari jamur Rhizopus oligosporus dan Rhizopus oryzae. Fungsi dari jamur /kapang tempe ini adalah akan menguraikan protein kompleks yang ada dalam kedelai menjadi senyawa-senyawa yang lebih sederhana agar mudah dicerna maupun diserap oleh tubuh. Selama proses penguraian (fermentasi) kedele menjadi tempe ternayata juga akan meningkatkan nilai gizi kedele. dan hemaglutinin (Chen, dkk., 2010; Yoo, dkk. 2009). Meskipun tempe merupakan makanan yang sangat baik nilai gizinya, karena mempunyai sifat yang mudah rusak dan tidak dapat disimpan dalam waktu lama, maka diperlukan suatu cara agar manfaat tempe tidak sia-sia maka diperlukan pengolahan tempe menjadi tepung tempe. Tempe dalam bentuk tepung akan lebih mudah ditambahkan pada produk pangan lain agar meningkatkan nilai protein pada pangan dan memperkaya nilai gizi (Putut, 2007).

Tepung tempe mempunyai banyak kelebihan, penggunaan tepung ini tidak saja meningkatkan kadar protein tetapi juga mudah dicampurkan dengan bahan lain (sumber karbohidrat). Keuntungan lainnya hasil penjualan tepung tempe lebih tinggi, meningkatkan nilai ekonomi tempe, serta meningkatkan gizi pada masyarakat (Astawan, 2008).

Lesitin adalah kelompok senyawa lemak yang ditemukan pada tanaman kedelai, bunga matahari, telur, susu, biji kapas. Lesitin kedelai digunakan sebagai pengemulsi makanan dan sumber protein yang sangat baik. Dalam industri roti, lesitin mempunya nilai lebih karena dapat memperbaiki kualitas adonan, tekstur, volume, browning, dan umur simpan, lesitin juga digunakan sebagai pengikat bahanbahan dalam es krim, selai kacang dan permen karet (Hartomo dan Widiatmoko, 1993).
Lesitin terdiri dari 19-21 \% fosfatidilkolin, $8-20 \%$ fosfatidiletanomalin, 20-21\% inositol fosfatida, 30\% minyak kedelai, 2-5\% sterol, 5\% karbohidrat bebas, $1 \%$ kadar air dan $5-10 \%$ fosfatida lainnya ( Eschliman,2015).

Dosis yang dianjurkan untuk makanan adalah $0.6 \%-1 \%$, misalnya pada tepung terigu yaitu 6-10g untuk $1 \mathrm{~kg}$ tepung terigu, sebagai emulsifier(margarin) $0.1 \sim$ $0.3 \%$, sedangkan sebagai wetting agent pada coklat ditambahkan $2-5 \%$. (Zeisel, 2001).

Abon sebagai salah satu produk yang disukai dan dikenal masyarakat, biasanya menggunakan bahan baku dari daging hewan yaitu, ayam, sapi, kambing, kuda, rusa maupun daging hewan lainnya. Abon mempunyai cita rasa yang khas kareana adanya penambahan bumbu. Bumbu yang ditambahkan sangat bervariasi dan sesuai dengan selera masyarakat masa kini. Bumbu yang dipergunakan dalam pembuatan abon adalah bawang merah, bawang putih, ketumbar, daun salam, daun jeruk, lengkuas, garam, gula merah, gula pasir serta jintan yang dihaluskan yang dicampur dengan bahan baku abon. Untuk menambah cita rasa biasanya ditambahkan santan kelapa yang dipakai sebagai sumber minyak untuk menggoreng abon. Pemasakan abon biasanya menggunakan api yang kecil agar tingkat kematangan merata dan mendapatkan warna yang diinginkan atau kuning kecoklatan (Lisdiana, 2005).

Standart mutu abon terdapat dalam SNI 01-3707-1995, dengan kadar protein maksimal $20 \%$, lemak maksimal $30 \%$, gula maksimal 30\%, kadar air maksimal 10\%, kadar karbohidrat maksimal 25\% dan kadar air maksimal 10\% (Jusniati dkk, 2017).

Inovasi-inovasi produk pangan non hewani (nabati) yang menyerupai produk pangan hewani sudah banyak beredar dimasyarakat antara lain abon dari jamur tiram, nangka muda dan lain-lain. Handayani dkk. (2016) dalam penelitiannya membuat produk abon nabati jamur tiram yang dikombinasikan dengan koro pedang dengan persentase berat jamur tiram $70 \%$ 
dengan variasi jenis bahan campuran koro pedang $30 \%$.

Abon termasuk diantara bahan makanan yang banyak disukai sebagian besar masyarakat kita, Hal ini memungkinkan produk abon nabati akan memiliki pasar yang baik (marketable), terutama bagi orang yang tidak boleh mengkonsumsi daging akibat penyakit yang dideritanya namun masih menginginkan mengkonsumsi abon. Disinilah abon nabati merupakan alternatif pilihan yang tepat. Abon yang terbuat dari bahan nabati memiliki tekstur, serat maupun rasa seperti abon dari bahan daging ayam atau daging hewan lainnya. (Muljawan dan Sugiarti, 2017).

Fortifikasi adalah penambahan suatu zat dalam bahan pangan tertentu untuk meningkatkan nilai gizinya. Fortifikasi pangan merupakan strategi untuk mengurangi kejadian kurang gizi di tingkat masyarakat maupun global (Siagian, 2003). Fortifikasi terhadap pangan diperbolehkan asal ditambahkan dengan bahan yang diinginkan. Fortifikasi harus dapat dikelola dengan baik dengan tujuan nilai organoleptiknya atau nilai inderawi yang berhubungan dengan selera makan konsumen tidak terabaikan. Hasil-hasil penelitian yang pernah dilakukan oleh Yasni, dkk (2018) menunjukkan bahwa dengan penambahan tepung tempe diatas $15 \%$ ke dalam adonan kue karasi mengurangi tingkat kesukaan konsumen terhadap warna, rasa dan aroma yang dihasilkan, dan mendapatkan kadar protein tertinggi sebanyak 25,40\%, kadar karbohidrat 53,54\% dan kadar lemak 4,84\%. Sedangkan menurut Rosida, dan Widodo (2015), penambahan tepung tempe kedele $7.5 \%$ akan meningkatkan kadar protein sebesar $9.886 \%$.

\section{METODE}

Bahan penelitian utama yang dibutuhkan adalah bonggol pisang. Bahan untuk fortifikasi berupa tepung tempe dan lesitin kedelai. Bahan penunjang berupa bumbu-bumbu antara lain: ketumbar bubuk, bawang putih bubuk, gula palm, gula pasir, daun jeruk purut dan daun salam serta bahan untuk menggoreng minyak goreng. Peralatan yang dipergunakan untuk membuat abon adalah peralatan masak, kompor, spiner. Metode yang digunakan secara eksperimental, dengan Rancangan Acak Lengkap (RAL) pola faktorial. Perlakuan pertama adalah penambahan tepung tempe kedele (T): $(5 \% \mathrm{w} / \mathrm{w}$, $10 \% \mathrm{w} / \mathrm{w}$ dan $15 \% \mathrm{w} / \mathrm{w})$ dan perlakuan kedua adalah penambahan Lesitin (L): $(3 \% \mathrm{v} / \mathrm{w}, 5 \% \mathrm{v} / \mathrm{w}$ dan $7 \% \mathrm{v} / \mathrm{w})$ sehingga diperoleh 9 kombinasi perlakuan. Uji proksimat dilakukan terhadap protein, lemak, kadar air dan karbohidrat, data yang terkumpul dianalisis dengan uji varian (analisis ragam) klasifikasi 2 arah. Jika ada perbedaan diantara perlakuan akan dilanjutkan dengan uji BNT 5\% untuk mengetahui pasangan-pasangan perlakuan mana saja yang berbeda nyata (Adinurani, 2016). Jika ada interaksi signifikan dilakukan pengujian melalui pendekatan polynomial orthogonal.

Pelaksanaan penelitian abon bonggol pisang langkah pertama adalah mengupas kulit luarnya sampai mendapatkan bagian yang putih dan memperkecil ukuran untuk memudahkan dalam proses memarut. Hasil parutan diperas untuk mengeluarkan airnya. Langkah kedua adalah mengukus bonggol pisang yang telah diperas selama 45 menit dengan tujuan menginaktifkan enzim serta mematangkan bahan dan selanjutnya didinginkan untuk ditimbang sesuai perlakuan. Tepung tempe dan lesitin ditimbang sesuai dengan perlakuan (tepung tempe $5 \% \mathrm{w} / \mathrm{w}, 10 \% \mathrm{w} / \mathrm{w}$ dan $15 \% \mathrm{w} / \mathrm{w}$ dan lesitin 3\%v/w, 5\%v/w dan $7 \% \mathrm{v} / \mathrm{w}$ ). Pada proses pembuatan abon ditambahkan bumbu-bumbu berupa bawang putih bubuk sebanyak $50 \mathrm{~g} / \mathrm{kg}$ bahan, ketumbar $50 \mathrm{~g} / \mathrm{kg}$ bahan, gula pasir $25 \mathrm{~g} / \mathrm{kg}$ bahan, gula palm $25 \mathrm{~g} / \mathrm{kg}$ bahan, garam $25 \mathrm{~g} / \mathrm{kg}$ bahan. Bahan abon yang sudah tercampur sesuai dengan perlakuan kemudian digoreng dalam wajan menggunakan minyak dengan api kecil sampai berwarna kecoklatan. (15 menit). 
Untuk mendapatkan abon bonggol pisang yang kering dilakukan penirisan dengan spiner yang bertujuan mengeluarkan sisa minyak sehingga didapatkan abon yang tidak mudah tengik dan daya simpannya lebih lama. Uji proksimat dilakukan untuk memperoleh data agar bisa dilakukan pembahasan dan menarik kesimpulan.

\section{HASIL DAN PEMBAHASAN \\ HASIL PENELITIAN}

Hasil analisis kadar lemak, kadar air, kadar karbohidrat abon bonggol pisang dapat di lihat pada Tabel 1.

Tabel 1. Nilai Rata-rata Kadar Lemak, Kadar Air, Kadar Karbohidrat, Kadar Protein Abon Bonggol Pisang

\begin{tabular}{|l|c|l|l|c|}
\hline Perlakuan & $\begin{array}{c}\text { Kadar Lemak } \\
(\%)\end{array}$ & $\begin{array}{c}\text { Kadar Air } \\
(\%)\end{array}$ & $\begin{array}{c}\text { Kadar } \\
\text { Karbohidrat }(\%)\end{array}$ & $\begin{array}{c}\text { Kadar Protein } \\
(\%)\end{array}$ \\
\cline { 1 - 4 } Tepung Tempe & $14.929 \pm 0.07^{\mathrm{a}}$ & $7.238 \pm 0.07^{\mathrm{a}}$ & $60.179 \pm 0.07^{\mathrm{a}}$ & $8.721 \pm 0.08^{\mathrm{a}}$ \\
\hline T1 $(5 \%)$ & $14.165 \pm 0.01^{\mathrm{a}}$ & $8.205 \pm 0.07^{\mathrm{a}}$ & $62.658 \pm 0.01^{\mathrm{ab}}$ & $9.028 \pm 0.09^{\mathrm{a}}$ \\
\hline T2 $(10 \%)$ & $13.850 \pm 0.02^{\mathrm{a}}$ & $8.230 \pm 0.05^{\mathrm{a}}$ & $64.642 \pm 0.09^{\mathrm{b}}$ & $12.921 \pm 0.03^{\mathrm{b}}$ \\
\hline T3 $(15 \%)$ & & & & \\
\hline Lesitin & & & & \\
\hline L2 $(5 \%)$ & $14.128 \pm 0.10^{\mathrm{a}}$ & $7.680 \pm 0.06^{\mathrm{a}}$ & $61.789 \pm 0.02^{\mathrm{a}}$ & $9.826 \pm 0.03^{\mathrm{a}}$ \\
\hline L3 $(7 \%)$ & $13.708 \pm 0.17^{\mathrm{a}}$ & $7.793 \pm 0.08^{\mathrm{a}}$ & $61.896 \pm 0.05^{\mathrm{a}}$ & $9.977 \pm 0.06^{\mathrm{a}}$ \\
\hline
\end{tabular}

Keterangan: Nilai rata-rata yang didampingi huruf yang berbeda menyatakan terdapat perbedaan yang signifikan

Hasil nilai rata-rata kadar lemak menunjukkan bahwa penambahan tepung tempe (T) maupun lesitin (L) keduanya tidak berpengaruh signifikan terhadap kadar lemak, demikian juga interaksi antar perlakuan (TL) tidak berpengaruh signifikan $(\mathrm{P}>0.05)$, menunjukkan bahwa penambahan tepung tempe dan lesitin yang berbeda memiliki pengaruh yang sama terhadap kadar lemak abon bonggol pisang.

Hasil nilai rata-rata pada kadar air memperlihatkan pemberian tepung tempe (T) maupun penambahan lesitin (L) keduanya tidak berpengaruh signifikan terhadap kadar air, demikian juga dengan interaksi antar perlakuan (TL) tidak menunjukkan pengaruh signifikan $(\mathrm{P}>0.05)$, artinya penambahan tepung tempe dan lesitin yang berbeda memiliki pengaruh yang sama terhadap kadar air abon bonggol pisang.

Hasil nilai rata-rata kadar karbohidrat memperlihatkan bahwa penambahan tempe (T) berpengaruh sangat signifikan terhadap kadar karbohidrat $(\mathrm{P}<0.01)$ dan pemberian lesitin (L) tidak berpengaruh signifikan
$(\mathrm{P}>0.05)$. Antar perlakuan juga tidak menunjukkan pengaruh interaksi yang signifikan terhadap kadar karbohidrat ( $>0.05)$. Hasil uji BNT penambahan tepung tempe terhadap karbohidrat menunjukkan bahwa antara $\mathrm{T} 1$ ( tepung tempe 5\%) dan T2 (tepung tempe 10\%) serta antara T2 (tepung tempe 10\%) dan T3 (tepung tempe 15\%), tidak menunjukkan perbedaan signifikan terhadap kadar karbohidrat. Perbedaan baru terlihat pada perlakuan T1 (tepung tempe 5\%) dengan T3 (tepung tempe 15\%). Rata-rata kadar karbohidrat tertinggi sebesar $64.642 \%$ pada penambahan tepung tempe kedele $15 \%$ dan rata-rata kadar karbohidrat terendah $(60.179 \%)$ pada penambahan tepung tempe sebesar $5 \%$.

Hasil nilai rata-rata perhitungan kadar protein menunjukkan penambahan tepung tempe (T) berpengaruh sangat signifikan terhadap kadar protein $(\mathrm{P}<0.01)$, sedangkan lesitin (L) tidak berpengaruh terhadap kadar protein $(\mathrm{P}>0.05)$. Uji BNT antara T1 (tepung tempe $5 \%$ ) dan T2 (tepung tempe 10\%) tidak ada pengaruh signifikan terhadap kadar 
protein. Perbedaan pengaruh baru terlihat pada perlakuan $\mathrm{T} 1$ (tepung tempe 5\%) dan T3 (tepung tempe 15\%), serta antara T2 (tepung tempe 10\%) dan T3 (tepung tempe 15\%).

\section{PEMBAHASAN}

Kadar lemak didalam abon bonggol pisang termasuk rendah. Menurut Rukmana (2005) bonggol pisang tidak mengandung lemak, disisi lain menurut Mardiah (1994) kandungan lemak pada tepung tempe kedele sebesar $24.5 \%$. sehingga penambahan tepung tempe kedele tidak memberikan pengaruh yang signifikan pada kadar lemak. Sedangkan Eschliman (2015) menyatakan kandungan lemak lesitin kedelai adalah $30 \%$. Kandungan lemak pada tepung tempe dan lesitin yang tidak terlalu tinggi inilah yang memungkinkan tidak memberikan pengaruh signifikan terhadap kadar lemak. Hasil analisis kadar lemak pada abon bonggol masih memenuhi SNI abon yaitu maksimal 30\% (Jusniati dkk, 2017).

Kadar air abon bonggol pisang masih tergolong rendah. Hal ini disebabkan karena kadar air tempe yang kecil sebesar $4.11 \%$ (Murni, 2014) dan kadar air lesitin hanya 1\% (Eschliman, 2015). Kadar air sangat penting pada bahan pangan karena dapat mempengaruhi tekstur, cita rasa dan daya awet. Kadar air yang tinggi berperan dalam perkembangbiakan bakteri, kapang dan khamir (Winarno, 2002). Kadar air dalam abon bonggol pisang yang diperoleh masih tergolong rendah dan memenuhi SNI abon maksimal 10\% (Jusniati dkk, 2017). Salah satu cara untuk mengurangi kadar air adalah dengan cara pemanasan (penggorengan), dimana air bebas yang terdapat dalam bahan langsung diuapkan oleh panas penggorengan dan minyak sebagai media perantara (Winarno, 2008). Kadar karbohidrat didalam abon pisang hasilnya cenderung tinggi. Hal ini disebabkan oleh tingginya kadar karbohidrat bonggol pisang itu sendiri sebesar $66.2 \%$ (Yuanita, 2008), dan ditambah dengan kadar karbohidrat tepung tempe $13.5 \%$ (Mardiah, 1994). Penambahan lesitin tidak berpengaruh signifikan dikarenakan kandungan karbohidratnya hanya sebesar 5\%
(Eschliman, 2015). Kandungan karbohidrat di dalam abon bonggol tidak memenuhi standart mutu SNI abon yaitu maksimal 25\% (Jusniati dkk, 2017). Karbohidrat juga memiliki peranan penting di dalam menentukan karakteristik bahan pangan misalnya tekstur, warna maupun rasa (Winarno, 2002).

Kadar protein dari abon pisang dipengaruhi oleh adanya penambahan tepung tempe. Semakin banyak tepung tempe kedele yang ditambahkan, akan menyebabkan kadar protein abon bonggol pisang semakin tinggi. Hal ini disebabkan karena tepung tempe memiliki kadar protein yang tinggi sebesar 49.60\% (Murni, 2014). Kadar protein yang terdapat pada abon bonggol pisang masih memenuhi standar mutu abon (SNI) yaitu maksimal 20\% (Jusniati dkk, 2017). Tepung tempe mengandung protein yang lebih tinggi karena selama fermentasi akan terjadi perombakan asam amino hasil aktivitas enzim proteolitik yang meningkatkan protein dan daya cernanya (Astawan, 2008).

\section{SIMPULAN DAN SARAN}

Penelitian ini menyimpulkan bahwa fortifikasi tepung tempe dan lesitin tidak berpengaruh signifikan terhadap kadar air dan kadar lemak abon bonggol pisang. Fortifikasi tepung tempe secara mandiri signifikan meningkatkan kadar karbohidrat dan kadar protein abon bonggol pisang. Fortifikasi lesitin secara mandiri tidak berpengaruh signifikan terhadap kadar karbohidrat dan kadar protein abon bonggol pisang.

Berdasarkan kesimpulan dari penelitian ini untuk membuat abon bonggol pisang disarankan menggunakan tepung tempe sebesar $15 \%$ untuk meningkatkan kadar protein dan tidak perlu menambahkan lesitin.

\section{UCAPAN TERIMAKASIH}

Terimakasih kepada Bapak Rektor Universitas 17 Agustus 1945 melalui LPPM Untag Surabaya yang telah membiayai kegiatan penelitian Hibah Perguruan Tinggi dengan judul " Fortifikasi Abon Bonggol Pisang dengan Tepung Tempe dan Lesitin) tahun anggaran 2019 dengan Kontrak Penugasan 
487.39/ST/003/LPPM/Lit/VII/2019. Penulis juga mengucapkan terimakasih kepada Kepala Laboratorium Pangan Untag Surabaya yang telah memberikan kesempatan dalam melakukan penelitian dan analisis bahan penelitian.

\section{DAFTAR PUSTAKA}

Adinurani, P.G 2016. Perancangan dan Analisis Data Percobaan Agro. Plantaxia, Yogyakarta.

Astawan, M. 2008. Sehat dengan Tempe (Panduan Lengkap Menjaga Kesehatan dengan Tempe). PT Dian Rakyat, Jakarta.

Chen, C.C.Shih, Y.C. Choo, P.W.S. Yu, B. 2010. Evaluating Nutritional Quality of Singl Stage and Two Single Stage Fermented Soybean Meal. Asian-Aust,J Anim. Sci.Vol.23, No. 5 : 598-606.

Eschliman, D. 2015. Ingredients: A Visual Exploration of 75 Additives and 25 Food Products. Oxford University Press, New York.

Handayani,T.M, Akhmad N dan Kurniawati. 2016. Karakteristik Si Bona (Formulasi Abon Nabati) dari Jamur Tiram (Pleurotus ostreatus) dengan Variasi Jenis Bahan Campuran .Fakultas Teknologi dan Industri Pangan. Universitas Slamet Riyadi, Surakarta.

Hartomo, A.J. dan Widiatmoko.1993. Emulsi dan Pangan Instant Berlesitin.Andi Offset. Jogyakarta.

Jusniati, Patang dan Kardiman.2017. Pembuatan Abon dari Jantung Pisang (Musa paradisiaca L).dengan Penambahan Ikan Tongkol. Jurnal Pendidikan Teknologi Pertanian Vol 4:365-370

Lisdiana. Membuat Aneka Abon. 2005. Kanisius, Yogyakarta.

Mardiah, 1994. Sifat Fungsional dan Nilai Gizi Tepung Tempe serta Pengembangan Produk Olahannya Sebagai Makanan Tambahan Bagi Anak. Institut Pertanian Bogor, Bogor.

Munadjim. 2006. Teknologi Pengolahan Pisang. PT Gramedia, Jakarta.
Murni,M. 2014. Pengaruh Penambahan Tepung Tempe Terhadap Kualitas dan Citarasa Naget Ayam. Balai Riset dan Standarisasi Industri Surabaya. Jawa Timur.

Muljawan, E.R dan Sugiarti. 2017 .Potensi Ekonomi Produk Abon Dan Dendeng Nabati. Jurnal Akses Pengabdian Indonesia Vol 1 No 2: 32-38

Putut I.P. 2007. LIPI Kembangkan Tepung Tempe). lipi.go.id/berita/lipikembangkan-tepung-tempe/204.

Rukmana, R. 2005. Usaha Tani Pisang. Kanisius, Yogyakarta.

Rosida, D.A dan Widodo. 2015. Peningkatan Kualitas Abon Nangka Muda Dengan Subsitusi Tepung Tempe. Kajian Dari Kandungan Protein Dan Tingkat Kesukaan Konsumen. Jurnal Teknik Industri HEURISTIC Vol.12 No. 1 hal 81-90.

Siagian, A. 2003. Pendekatan Fortifikasi Pangan untuk Mengatasi Masalah Kekurangan Zat Gizimikro. Fakultas Kesehatan Masyarakat. Universitas Sumatera Utara, Medan.

Yasni, W., Ansharullah,dan Nurasyik. 2018. Pengaruh Substitusi Tepung Tempe Terhadap Penilaian Organoleptik Dan Nilai Gizi Kue Karasi. Sains dan Teknologi Pangan Vol. 3, No.6, P. 1448-1459.

Winarno, F.G. 2002. Kimia Pangan dan Gizi. PT. Gramedia Pustaka Utama, Jakarta.

Winarno, F.G. 2008. Kimia Pangan dan Gizi Edisi Terbaru. M-Brio Press Bogor.

Yuanita. 2008, Pabrik Sorbitol dari Bonggol Pisang (Musa paradisiaca) dengan proses Hidrogenasi Katalitik. Jurnal Ilmiah Teknik Kimia. ITS, Surabaya.

Suyanti dan Supriyadi. 2008. Pisang, Budidaya, Pengolahan dan Prospek Pasar. Panebar Swadaya Jakarta.

Yoo, J.S. Jang,H.D. Cho, J.H. Lee, J.H. Kim, I.H. 2009. Effect of fermented soy protein on nitrogen balance and apparent fecal and ileal digestibility in weaned pigs. Asian-Aust.J. Anim. Sci.Vol.22, No.8: 1167 -1173. 
Zeisel, SH. 2001 Makanan Alergi dan Jaringan Anafilaksis. Diadaptasi dari Alergi Makanan News, Vol. 2, No 1. 2. 